\title{
$85^{\text {Th }}$ Percentile Speed Prediction Model For Bode Saadu- Jebba Road In Kwara State, Nigeria
}

\author{
O. O. Joseph ${ }^{1, *}$ and A. I.Dauda ${ }^{2}$ \\ ${ }^{1}$ Civil Engineering Department, Federal University of Technology Akure Nigeria \\ ${ }^{2}$ Federal Road Maintenance AgencyIlorin Field Headquarter Nigeria
}

Received 22 November 2010; Revised 14 December 2010; Accepted 25 January 2011

\begin{abstract}
Among the roadway element, horizontal alignment has long been recognized as having a significant effect on vehicle speeds. Unexpectedly tight horizontal curves can lead to accidents as drivers try to negotiate them at too high a speed. Design features, such as curvature and super elevation, are directly related to, and vary appreciably with design speed; while the $85 \%$ percentile speed of light vehicle is commonly used as a basis for the design i.e. the speed exceeded by only $15 \%$ of the vehicles. Reconnaissance survey of the area was carried out; geometric data were extracted from the working drawing while instantaneous speed were measured manually using stop watch at selected locations. Regression analysis of both the geometric data extracted and the $85^{\text {th }}$ percentile speed evaluated were performed using Statistical Package for Social Sciences (SPSS to formulate simple mathematical model for operating speed. The coefficient of determination(R) and coefficient of determination $\left(\mathrm{R}^{2}\right)$ obtained were $85.2 \%$ and $72.6 \%$ respectively.In the reported model for 85 th percentile vehicular speed, regression parameters were statistically significant for variables, the relationship exists between all the parameters since the both output shows $\mathrm{R}-\mathrm{sq}$ value was more than $50 \%$. It can be conclude that, the operating speed of the vehicle depends on the Radius (R); Length of curve $\left(\mathrm{L}_{\mathrm{c}}\right)$; Tangent lengths $\left(\mathrm{T}_{\mathrm{L}}\right)$; Gradient $(\mathrm{G})$; and Super elevation (e).

It is recommended that the model equation obtained could be used to obtained design speed in the study location and similar road network; while a large national research effort aimed at developing speed models for Nigerian situation should be conducted, the results will aid in the development of consistent design and traffic control
\end{abstract}

Keywords: polymer electroluminescent devices; energy level measurement; interface optimization.

Abstract

Key Words: Horizontal Alignment, Speed, Accident, Regression Analysis and Traffic Control

\section{Introduction}

Horizontal alignment is one of the most important features influencing the efficiency and safety of a highway. A poor design will result in lower speeds and resultant reduction in highway performance in terms of safety and comfort; it may increase the cost of vehicle operations and lower the highway capacity. Horizontal alignment design involves the understanding on the design aspects such as design speed and the effect of horizontal curve on the vehicles. The horizontal curve design elements include design of super elevation, extra widening at horizontal curves, design of transition curve, and set back distance.

The presence of horizontal curve imparts centrifugal

\footnotetext{
*E-mail address: oyedepoo@yahoo.co.uk

ISSN: 1791-2377 @ 2011 Kavala Institute of Technology. All rights reserved.
}

force which is reactive force acting outward on a vehicle negotiating it. Centrifugal force depends on speed and radius of the horizontal curve and is counteracted to a certain extent by transverse friction between the tyre and pavement surface. On a curved road, this force tends to cause the vehicle to overrun or to slide outward from the centre of road curvature. However, accidents often occur on horizontal curves are a cause for concern in all countries, whatever the level of development of their road system. A recent study has found that in Denmark, about $20 \%$ of all personal injury accidents and $13 \%$ of all fatal accidents occur on curves in rural areas; and in France, over 20\% of fatal accidents occur on dangerous curves in rural areas [1]. Accidents on bends are undoubtedly a major problem in many developing countries, although theproportion of such accidents is dependent upon both the topography and demography of each country. 
The geometric design of the roads has been studied for many years;many researches had been performed on several elements of geometric design such as horizontal alignment and vertical alignment, while several studies have investigated the relationships between the various speed elements. Some of the studies have tried to predict operating speed using roadway characteristics; others have attempted to identify the relationship between posted speed limit and operating speed. Many studies concern on the design of the alignments and the operating speed of the vehicle while maneuvering along the alignments. Most of these researches had been widely perform in United States, Europe, Japan and other developing country. The good geometric design means providing an appropriate level of mobility and land use access for drivers and pedestrians while maintaining a high degree of safety. Geometric design can be referred to the selection of roadway elements that include the horizontal alignment, vertical alignment, cross section and roadside of the highways or streets. Many studies concerned on the design of the alignments and the operating speed of the vehicle while maneuvering the alignments. The operating speed of the highway can be seen as the speed observed at the site which driver can travels on a given highway under favorable weather conditions and under prevailing traffic conditions without at any time exceeding the design speed on a section by section basis.

Several studies have been articulated on speed prediction on horizontal alignment; In Germany analyzed the horizontal alignment of two-lane highways and developed several consistency criteria for the design characteristic[2]. It was suggested that the difference between the 85th percentile operating speed and the design speed should be smaller than a set of criteria for good, acceptable, and bad design. Studied operating speeds on 120 two-lane rural alignments with low, intermediate and high-speed[3]. He observed that the 85th percentile curve speeds were dominantly influenced by both the driver's desired speed and the curve radius. The model is represented in equation $\mathrm{i}$ :

$\mathrm{V} 85=53.8+0.464 \mathrm{VF}-3.26(1 / \mathrm{R}) * 10^{3}+8.5(1 / \mathrm{R})^{2} * 10^{4}$

$\mathrm{R}^{2}=0.92$

Where

V85 = Estimate of 85 th percentile curve speed $(\mathrm{km} / \mathrm{h})$, $\mathrm{VF}=$ Desired speed of the 85 th percentile $(\mathrm{km} / \mathrm{h})$,

$\mathrm{R}=$ Curve radius $(\mathrm{m})$, and

$\mathrm{R}^{2}=$ Coefficient of determination.

Studied operating speeds of passenger vehicles on 56 alignments in fourstates[4]. The relationship between operating speeds and degree of curve was quantified by thefollowing model in equation 2 :

$\mathrm{V}_{85}=150.08-4.14 \mathrm{DC}$

$\mathrm{R}^{2}=0.84$

Where:

$\mathrm{V}_{85}=85^{\text {th }}$ percentile speed $(\mathrm{km} / \mathrm{h})$, and

$\mathrm{DC}=$ Degree of curve $($ degree $/ 30 \mathrm{~m})$,
Likewise, Krammes et el. in their study presented several design-consistency models to evaluate consistency for rural two-lane highways[5]. The $85^{\text {th }}$ percentile speed was predicted based on such independent parameters as the degree of curve, length of curve, and the deflection angle. Their speed prediction model was utilized for the development of the speed profile, from which the consistency model subsequently was developed. Resolution of the annual meeting of the American Association of state highway officials declare that $85^{\text {th }}$ percentile speed should be given privacy consideration in speed zones below $80.65 \mathrm{~km} / \mathrm{h}$ and $90^{\text {th }}$ percentile speed is to be given primary consideration in establishing speed zones of 50 miles per hour above[6]. California State Traffic Manual reported that establishing a speed limit at less than the $85^{\text {th }}$ percentile (critical speed) generally results in an increase in accident rate.

Accordingly, Mc Fadden and Elefteriadou [7] used the boostrapping technique to sample, formulate, and validate the operating speed-prediction models that were previously proposed by Krammes et al.[5]. In all the models tested, they found no significant differences between the $85^{\text {th }}$ percentile speed predicted by the model and the observed $85^{\text {th }}$ percentile speed. Also, Anderson and Krammes estimated the reduction in $85^{\text {th }}$ percentile speeds from the approach tangent to be midpoint of the following curve[8]. They found that a statistically significant existed between mean speed reduction and mean accident rate: sites with higher speed reductions showed higher accident rates. Krammes and Hayders discussed the interactive Highway Safety Design Model (IHSDM), which has been in development in the U.S. for several years. This model includes a consistency module with two aspects; large differences between the assumed design speed and the $85^{\text {th }}$ percentile speed and large charges is the $85^{\text {th }}$ percentile speed between tangents and curve.

Prediction and estimation of speeds on two lane rural highways are of great significance to planners and designers, therefore, all speed prediction equations, should be validated, and the accuracy of their results should be evaluated. Thus, the primary objective of the research is to formulate a mathematical model to predict the $85^{\text {th }}$ percentile speed that can be used to evaluate the design speed consistency of passenger vehicles along Bode Saadu - Jebba road in Kwara State, Nigeria.

\section{The Study Area}

The Bode Saadu - Jebba road $(25 \mathrm{~km})$ is a section of TransSahara trade route that links the Northern States with Sea, South West Nigeria. The road is heavily trafficked with heavy trucks accounting for the bulk of the traffic. The road traverses through a hilly and flat terrain, consisting mainly of laterite, clay and sandy soils. The rural settlements located along the route aside from the sub-urban towns of Bode Saadu and Jebba are Adekanbi, Ile Pupa, Biribiri, Onipako. The carriageway width is $7.3 \mathrm{~m}$ and the shoulders is $2.75 \mathrm{~m}$ wide each. The pavement structure is made up of $150 \mathrm{~mm}$ thick each of sub-base and crushed stone base with asphaltic concrete binder and wearing courses, $60 \mathrm{~mm}$ and $40 \mathrm{~mm}$ thickness respectively. The road pavement is 
distressed and it is characterized with potholes, ruts and completely failed sections.

The road was constructed in the 60 's, but fully rehabilitated with improved geometric features in 1983 by MessrsSolelBonel Nig. Ltd on behalf of Federal Ministry of Works. The road had since undergone various degrees of maintenance activities. Presently the Federal Ministry of Works is embarking on a limited rehabilitation works on the road. It is being handled by MessrsBulletine Construction Co. Ltd. The vegetation of this area belongs to the Guinea Savanah with woodland and tall grasses. The minimum average temperature ranges between $21^{\circ} \mathrm{c}$ and $25^{\circ} \mathrm{c}$ while the maximum average temperature ranges between $30^{\circ} \mathrm{c}$ to $35^{\circ} \mathrm{c}$. There are local industries flourishing along the road through the adoption of appropriate local technology. Production of these industries includes pounding mortals and pestles production, carved and uncarved calabashes. Figure 1 below shows the location map of the study location.

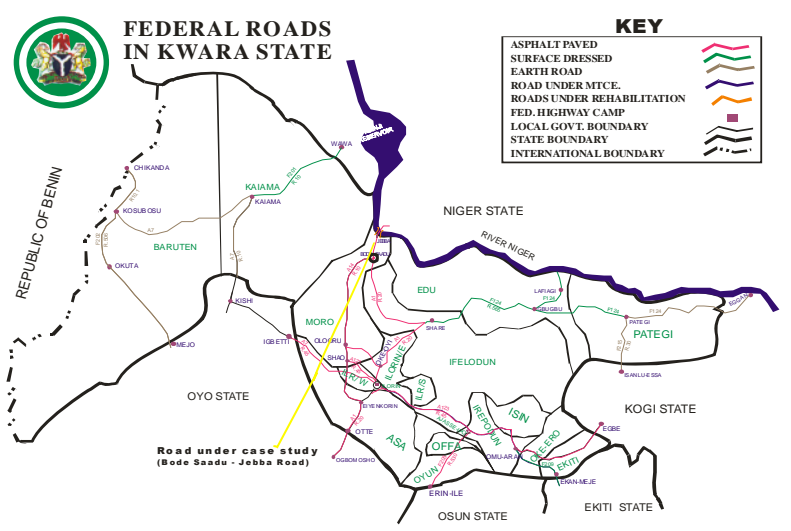

Fig. 1. Location Map of The Study Area.

\section{Research Approach}

Speed data were collected for all types of vehicles in the traffic stream under free- flow conditions at point of minimum radius along the study area using video recording camera; an average of 100 vehicles were collected at 21 locations while the speed data were later extracted by replaying the video cassette. The 85th percentile speed values were evaluated and used as dependent variables, while geometric data such as super-elevation, curve radius, length of curve, and gradient among others wereextracted from the design drawing and used as independent variables to develop a model capable of predicting the vehicles' operating speed at different points on a horizontal curve; however, road surface quality were represented with dummy variable. To define the relationship between operating speed with other parameters; a statistical analysis was carried out taking into consideration the data on speed in both directions along curves using Statistical Package for Social Sciences (SPSS).

\section{Definition of Variables}

The figure 2 below shows a typical circular curve with various defining parameters as follows:

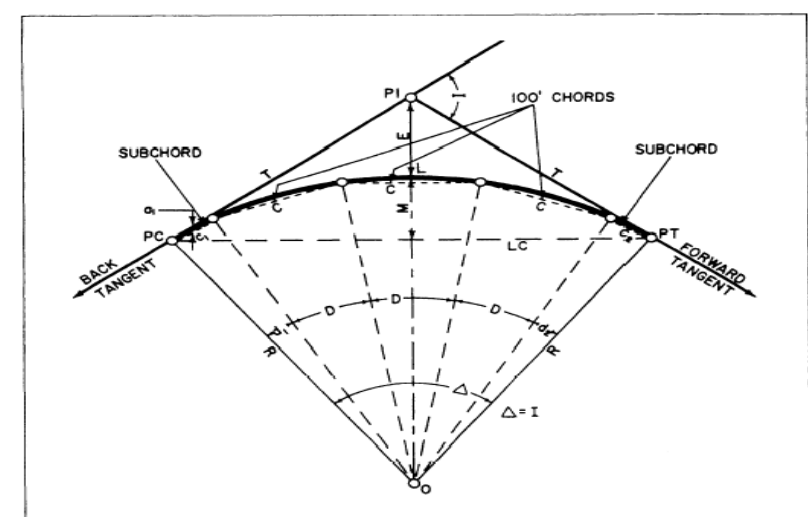

Fig. 2. A Typical Simple Circular Curve

- Point of Intersection (PI). The point of intersection is the point where the back and for-ward tangents intersect. Sometimes, the point of intersection is designated as $\mathrm{V}$ (vertex).

- Intersecting Angle. The intersecting angle is the deflection angle at the PI. Its value is either computed from the preliminary traverse angles or measured in the field.

- A Central Angle. The central angle is the angle formed by two radii drawn from the center of the circle $(\mathrm{O})$ to the PCand PT. The value of the central angle is equal to the Iangle.

- $\operatorname{Radius}(\mathrm{R})$. The radius of the circle of which the curve is an arc, or segment. The radius is always perpendicular to back and forward tangents.

- Point of Curvature (PC). The point of curvature is the point on the back tangent where the circular curve begins. It is sometimes designated as $B C$ (beginning of curve) or $T C$ (tangent to curve).

- Point of Tangency(PT). The point of tangency is the point on the forward tangent where the curve ends. It is sometimes designated as $E C$ (end of curve) or $C T$ (curve to tangent).

- Point of Curve (POC). The point of curve is any point along the curve.

- Length of Curve (L). The length of curve is the distance from the PC to the PT, measured along the curve.

- Tangent Distance (T). The tangent distance is the distance along the tangents from the PI to the PC or the PT. These distances are equal on a simple curve.

- Long Chord (LC). The long chord is the straight-line distance from the PC to the PT. Other types of chords are designated as follows:

- External Distance (E).The external distance (also called the external secant) is the distance from the PI to the midpoint of the curve. The external distance bisects the interior angle at the PI.

- Middle Ordinate (M). The middle ordinate is the distance from the midpoint of the curve to the midpoint of the long chord. The extension of the middle ordinate bisects the central angle.

- Degree of Curve (D). The degree of curve defines the sharpness or flatness of the curve.

- Superelevation(e): It is tilting the roadway to help offset centripetal forces developed as the vehicle goes around a 
curve. Along with friction they are what keep a vehicle from going off the road.

\section{Data Analysis and Result}

The summary of geometric data extracted from the working drawing for the study location and field data collected on operating speed is shown in table 1 below.

\subsection{Regression Analysis}

Regression analysis had been used to calibrate and determine if any relationship exists and fits the data well between the parameters in order to develop a model that will present the speed characteristics for the curves. If a linear relationship exists between an independent and dependent variable, it is also useful to measure the strength of the linear relationship. Multiple regression analysis was used to develop a model for predicting the $85^{\text {th }}$ percentile speed by using combination data from overall sites. The following equation for the prediction of operating speed on curveswas obtained.

$$
\begin{aligned}
\mathrm{V}_{85 \mathrm{th}}= & 55.445-0.009 \mathrm{R}+0.007 \mathrm{~L}_{\mathrm{c}}-1.053 \mathrm{D} \\
& +0.079 \mathrm{~T}_{\mathrm{L}}+1.642 \mathrm{G}+643.803 \mathrm{e}
\end{aligned}
$$

Coefficient of determination " $R$ " $=0.852$ which means that there is $85.2 \%$ linear relationship between the dependent variables and independent variables.

Coefficient of determination " $\mathrm{R}$ " $=0.726$ which means that $72.6 \%$ of the dependent variable is explained by the independent variables while the remaining $27.4 \%$ is explained by variables not included in the model. However, the value is strong enough to predict $85^{\text {th }}$ percentile speed in the study area.

\subsection{Concluding Remark}

In the reported model for 85th percentile vehicular speed, regression parameters were statistically significant for variables, the relationship exists between all the parameters since the both output shows $\mathrm{R}$ - sq value was more than $50 \%$. It can be conclude that, the operating speed of the vehicle depends on the Radius (R); Length of curve $\left(\mathrm{L}_{\mathrm{c}}\right)$; Tangent lengths $\left(\mathrm{T}_{\mathrm{L}}\right)$; Gradient $(\mathrm{G})$; and Super elevation (e). However, it is recommended that:

- the above model equation could be used to obtained design speed in the study location and similar road network.

- Conduct a large national research effort aimed at developing speed models. Results will aid in the development of consistent design and traffic control.

\begin{tabular}{|c|c|c|c|c|c|c|c|c|c|c|c|c|c|c|}
\hline $\mathbf{S} / \mathbf{N}$ & Chainage & $\begin{array}{l}V_{85 \text { th }} \\
\text { percent }\end{array}$ & $\begin{array}{l}\text { Radius } \\
\text { of } \\
\text { curve } \\
(\mathbf{R}) \mathrm{m} \\
\end{array}$ & $\begin{array}{l}\text { Length } \\
\text { of curve } \\
\text { (L)m }\end{array}$ & $\begin{array}{l}\text { Deflection } \\
\text { angle } \\
\text { (D) } 0^{0} 0^{1} 0^{11}\end{array}$ & 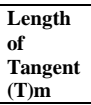 & $\begin{array}{l}\text { Shoulder } \\
\text { width } \\
\text { (SH)m }\end{array}$ & $\begin{array}{l}\text { Pavement } \\
\text { width } \\
\text { (W)m }\end{array}$ & $\begin{array}{l}\text { Grade } \\
(\%)\end{array}$ & $\begin{array}{l}\text { Super } \\
\text { elevation } \\
\text { (e) }\end{array}$ & VPC & $\stackrel{\text { VPI }}{\longrightarrow}$ & VPT & Remarks \\
\hline 1. & $73+125$ & 43 & 400 & 175.45 & $25^{0} 7^{1} 51^{11}$ & 89.16 & 2.75 & 7.3 & 3.7 & 0.02 & $73+005.84$ & $73+095$ & $73+180.29$ & Severe Ruts \\
\hline 2. & $73+925$ & 68 & 400 & 240.16 & $34^{0} 24^{1} 3^{11}$ & 123.82 & 2.75 & 7.3 & 3.7 & 0.05 & $73+716.18$ & $73+840$ & $73+956.34$ & $\begin{array}{l}\text { Pavement } \\
\text { surface good }\end{array}$ \\
\hline 3. & $74+650$ & 50 & 900 & 446.50 & $28^{0} 25^{1} 31^{11}$ & 227.95 & 2.75 & 7.3 & 1.9 & 0.01 & $74+402.05$ & $74+630$ & $74+848.55$ & Severe cracks \\
\hline 4. & $75+500$ & 71 & 600 & 206.43 & $19^{0} 42^{1} 47^{11}$ & 104.25 & 2.75 & 7.3 & 4.2 & 0.04 & $75+375.75$ & $75+480$ & $75+582.18$ & Ruts \\
\hline 5. & $77+050$ & 58.50 & 500 & 200.77 & $23^{0} 0^{1} 23^{11}$ & 101.75 & 2.75 & 7.3 & 3.4 & 0.03 & $76+928.25$ & $77+030$ & $77+129.02$ & $\begin{array}{l}2 \text { N0.s deep } \\
\text { potholes }\end{array}$ \\
\hline 6. & $78+250$ & 64 & 800 & 149.05 & $10^{0} 40^{1} 29^{11}$ & 74.74 & 2.75 & 7.3 & 2.3 & 0.02 & $78+170.26$ & $78+245$ & $78+319.31$ & Pavement good \\
\hline 7. & $79+425$ & 70 & 800 & 208.64 & $14^{0} 56^{1} 35^{11}$ & 104.92 & 2.75 & 7.3 & 2.2 & 0.03 & $79+350.08$ & $79+455$ & $79+558.72$ & $\begin{array}{l}\text { Dangerous } \\
\text { potholes at }\end{array}$ \\
\hline 8. & $79+775$ & 72 & 650 & 150.79 & $13^{0} 17^{1} 30^{11}$ & 75.73 & 2.75 & 7.3 & 2.1 & 0.04 & $79+704.27$ & $79+780$ & $79+855.06$ & $\begin{array}{l}\text { Edge of } \\
\text { pavement, } \\
\text { good pavement }\end{array}$ \\
\hline 9. & $80+225$ & 76 & 651 & 136.50 & $12^{0} 0^{1} 48^{11}$ & 68.50 & 2.75 & 7.3 & 0.7 & 0.04 & $80+166.50$ & $80+235$ & $80+303.00$ & Pavement good \\
\hline 10. & $81+400$ & 71 & 340 & 153.59 & $25^{0} 52^{1} 58^{11}$ & 78.13 & 2.75 & 7.3 & 0.2 & 0.07 & $81+306.87$ & $81+385$ & $81+460.46$ & $\begin{array}{l}1 \text { No. pothole } \\
\text { Pavement very }\end{array}$ \\
\hline 11. & $82+200$ & 41 & 1000 & 136.88 & $7^{0} 50^{1} 35^{11}$ & 68.55 & 2.75 & 7.3 & 1.5 & 0.01 & $82+131.45$ & $82+200$ & $82+268.33$ & $\begin{array}{l}\text { bad need total } \\
\text { scarification }\end{array}$ \\
\hline 12. & $83+550$ & 80 & 400 & 155.25 & $22^{0} 14^{1} 18^{11}$ & 78.62 & 2.75 & 7.3 & 3.5 & 0.07 & $83+486.38$ & $83+565$ & $83+641.63$ & Pavement good \\
\hline 13. & $84+475$ & 77 & 850 & 184.65 & $12^{0} 26^{1} 49^{11}$ & 92.69 & 2.75 & 7.3 & 3.6 & 0.03 & $84+387.31$ & $84+480$ & $84+571.96$ & Pavement good \\
\hline 14. & $85+325$ & 67 & 500 & 238.97 & $27^{0} 23^{1} 01^{11}$ & 121.81 & 2.75 & 7.3 & 3.1 & 0.04 & $85+232.19$ & $85+354$ & $85+471.16$ & $\begin{array}{l}\text { Pavement good } \\
\text { Approach }\end{array}$ \\
\hline 15. & $86+500$ & 70 & 2000 & 372.60 & $10^{0} 40^{1} 28^{11}$ & 181.84 & 2.75 & 7.3 & 2.0 & 0.01 & $86+313.16$ & $86+495$ & $86+685.76$ & $\begin{array}{l}\text { potholes plus } \\
\text { ruts }\end{array}$ \\
\hline 16. & $87+650$ & 64 & 430 & 239.55 & $31^{0} 55^{1} 7^{11}$ & 122.97 & 2.75 & 7.3 & 1.8 & 0.04 & $87+542.03$ & $87+665$ & $87+781.58$ & Severe cracks \\
\hline
\end{tabular}

Table 1. Geometric Data for BODE - SAADU - JEBBA - ROAD HORIZONTAL ALIGNMENT INDICES

GEOMETRIC DATA

\begin{tabular}{|c|c|c|c|c|c|c|c|c|c|c|c|c|c|c|}
\hline $\mathbf{S} / \mathbf{N}$ & Chainage & $\begin{array}{l}V_{\text {85th }} \\
\text { percent }\end{array}$ & $\begin{array}{l}\text { Radius } \\
\text { of curve } \\
\text { (R)m }\end{array}$ & 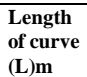 & $\begin{array}{l}\text { Deflection } \\
\text { angle } \\
\text { (D) } 0^{0} 0^{1} 0^{11}\end{array}$ & $\begin{array}{l}\text { Length of } \\
\text { Tangent } \\
\text { (T)m }\end{array}$ & $\begin{array}{l}\text { Shoulder } \\
\text { width } \\
\text { (SH)m }\end{array}$ & $\begin{array}{l}\text { Pavement } \\
\text { width } \\
\text { (W)m }\end{array}$ & $\begin{array}{l}\text { Grade } \\
(\%)\end{array}$ & $\begin{array}{l}\text { Super } \\
\text { elevation } \\
\text { (e) }\end{array}$ & VPC & VPI & $\stackrel{\text { VPT }}{\longrightarrow}$ & Remarks \\
\hline 17. & $88+275$ & 42 & 390 & 211.13 & $31^{0} 1^{0} 4^{11}$ & 108.22 & 2.75 & 7.3 & 3.5 & 0.20 & $88+186.78$ & $88+295$ & $88+397.91$ & $\begin{array}{ll}\text { Cracks } & \text { with } \\
\text { surface } & \\
\text { peeling } & \end{array}$ \\
\hline 18. & $89+225$ & 49 & 2800 & 223.33 & $4^{0} 34^{1} 12^{11}$ & 111.72 & 2.75 & 7.3 & 3.5 & 0.04 & $89+113.28$ & $89+225$ & $89+336.61$ & $\begin{array}{l}\text { Multiple } \\
\text { potholes }\end{array}$ \\
\hline 19. & $90+925$ & 67 & 1350 & 540.49 & $\begin{array}{l}22^{0} \\
21^{11}\end{array} \quad 56^{1}$ & 273.91 & 2.75 & 7.3 & 0.7 & 0.02 & $90+646.09$ & $90+920$ & $91+186.58$ & $\begin{array}{l}\text { Pavement } \\
\text { good }\end{array}$ \\
\hline 20. & $91+850$ & 59 & 900 & 412.26 & $\begin{array}{l}16^{0} \quad 49^{1} \\
42^{11}\end{array}$ & 133.13 & 2.75 & 7.3 & 1.9 & 0.02 & $91+680.87$ & $91+814$ & $92+093.13$ & $\begin{array}{l}\text { Water } \\
\text { ponding } \\
\text { on }\end{array}$ \\
\hline 21. & $92+900$ & 70 & 2500 & 881.78 & $\begin{array}{ll}20^{0} & 12^{1} \\
33^{11} & \\
\end{array}$ & 445.52 & 2.75 & 7.3 & 0.9 & 0.01 & $92+449.48$ & $92+895$ & $93+331.26$ & $\begin{array}{l}\text { carriageway } \\
\text { Pavement } \\
\text { good }\end{array}$ \\
\hline & $\begin{array}{l}\text { VPC- } \\
\text { VPI - } \\
\text { VPT - }\end{array}$ & $\begin{array}{l}\text { Beginn } \\
\text { Point o } \\
\text { End of }\end{array}$ & $\begin{array}{l}\text { of the C } \\
\text { tersectio } \\
\text { Curve }\end{array}$ & & & & & & & & & & & \\
\hline
\end{tabular}

HORIZONTAL ALIGNMENT INDICES 


\section{References}

1. Herrstedt L and Griebe P (2001) Safer signing and marking of horizontal curves on rural roads. Traffic Engineering and Control March 2001 pp 82-87, London

2. Lamm, R. and Choueriri, E. (1995), "The relationship between highway safety and geometric design consistency: A case study."Road Safety in Europe and Strategic Highway Research Program (SHRP), pp 133-151

3. McLean, J.R. (1979). An Alternative to the Design Speed Concept for Low Speed Alinement Design. Transportation Research Record 702, TRB, National Research Council, Washington D.C.

4. Glennon, J. C. Hardward, O. W; Free, S; and Gray, C. W. (1978); "Highway design consistency and systematic design related to highway safety”National Research Council, Washington D. C., Pg. $47-51$
5. Krammes R.A.(1995): Horizontal Alignment Design Consistency for Rural Two lane Highways, Publication No. FHWA-RD-94-034, Federal Highway Administration, Washington DC

6. AASHTO (1969), An Extract from resolution of the annual meeting of the American Association of State Highway Officials on $85^{\text {th }}$ Percentile Speed

7. MC Fadden, J. and Elefteriadou, L. (1997) "Formulation and Validation of Operating speed - based design consistency models by bootstrapping" NationalResearch Council, Washington D. C., Pg. $97-103$

8. Anderson, I.B., and Krammes, R.A. (2000), "Speed reduction as a surrogate for accident experience at horizontal curves on rural two-lane highways.", Transportation Research Record 1701, National Research Council, Washington D.C, pp 86-94 